\title{
Structure and Properties of Ni-B/Graphene Oxide Composite Coatings Produced by Chemical Reduction Method
}

\author{
Grzegorz Cieślak and Maria Trzaska
}

\author{
(Submitted August 30, 2019; in revised form February 21, 2020; published online March 12, 2020)
}

\begin{abstract}
A nickel-boron (Ni-B)/graphene composite coatings were produced using chemical reduction method on a steel substrate. These composites were compared to Ni-B coatings without graphene embedded into the matrix. Graphene in the form of an aqueous suspension of graphene oxide flakes was used. Graphene was characterized by single-layered flakes about $0.5 \mu \mathrm{m}$ in size. The coatings produced were characterized by an amorphous structure. The incorporation of graphene into the Ni-B matrix affects the surface topography and morphology of the coatings produced. The addition of graphene strengthened the coating material. An increase in the hardness $(\sim 1100 \mathrm{HKO.025})$ was noted for Ni-B/graphene composite coatings compared to the hardness $(\sim 950 \mathrm{HK0.025})$ of the Ni-B coatings without a built-in dispersion phase. Composite coatings also exhibited a better corrosion resistance than the coatings without embedded graphene.
\end{abstract}

Keywords chemical reduction method, composite coatings, graphene, Ni-B

\section{Introduction}

In recent years, nickel alloy coatings deposited by chemical reduction methods have been gaining an increasing interest. Nickel alloy coatings, due to their relatively simple manufacturing methods and the possibility of covering elements with complicated shapes and favorable properties, e.g., high hardness, abrasion resistance, and corrosion resistance, have become important in many industries as surface layers improving the performance of the final products (Ref 1-6). The electroless deposition of nickel alloys is also used to cover the particles of various materials with a thin metallic layer, such as graphene (Ref 7), carbon nanotubes (Ref 8, 9), $\mathrm{SiO}_{2}(\operatorname{Ref} 10)$, $\mathrm{TiH}_{2}$ (Ref 11), and SiC (Ref 12). In addition to the widely used Ni-P coatings, Ni-B coatings, which also have good properties, are becoming increasingly popular in recent years (Ref 13-17). The material properties of such coatings can be further improved by incorporating other particles into the alloy matrix, e.g, $\mathrm{SiC}$ (Ref 18), $\mathrm{Al}_{2} \mathrm{O}_{3}$ (Ref 19), $\mathrm{TiO}_{2}$ (Ref 20), or $\mathrm{Si}_{3} \mathrm{~N}_{4}$ (Ref 21). It is interesting to incorporate, as the dispersive phase, allotropic varieties of carbon including graphene and its derivatives into the composites. The influence of graphene on

This article is an invited submission to JMEP selected from presentations at The XXII Physical Metallurgy and Materials Science Conference: Advanced Materials and Technologies (AMT 2019) held June 9-12, 2019, in Bukowina Tatrzańska, Poland, and has been expanded from the original presentation.

Grzegorz Cieślak and Maria Trzaska, Łukasiewicz - Institute of Precision Mechanics, Warsaw, Poland. Contact e-mail: grzegorz.cieslak@imp.edu.pl. the properties of electroless-deposited Ni-P coatings has been examined (Ref 22-24). These studies have shown that the incorporation of graphene into the Ni-P coating increases the hardness and abrasion resistance as well as improving the corrosion resistance. There are differences between the nickel alloy coatings when bound by different alloying elements $(\mathrm{P}$, B). Depending on the alloy composition, these coatings may have different properties. In the case of $\mathrm{Ni}-\mathrm{B}$ coatings, an increase in the hardness of such coatings is noticeable when compared to Ni-P. In addition, by incorporating graphene into the Ni-B matrix, it is possible to increase the hardness even further and achieve values of $\sim 1000 \mathrm{HK} 0.025$, which is similar to the hardness of chromium coatings (Ref 25). Chromium (VI) compounds are sanctioned by the European Union as highly carcinogenic substances (Ref 26) and are, therefore, undesirable. A search for new materials that can replace $\mathrm{Cr}$ is required.

Composite coatings with a Ni-B alloy matrix and a dispersion phase, in the form of graphene, produced by a chemical reduction method are the subject of the presented research. We deposited Ni-B/graphene composite coatings and studied the influence of the incorporation of graphene oxide into the Ni-B matrix on the structure and properties of the coatings produced.

\section{Materials and Methods}

$\mathrm{Ni}$-B/graphene composite coatings and Ni-B alloy coatings were deposited on a carbon steel ASTM A573 substrate. Before processing, the substrate was mechanically ground on papers with a 200-1000 gradation, degreased with acetone, and digested in $15 \% \mathrm{H}_{2} \mathrm{SO}_{4}$. The deposition process was carried out in a bath containing: nickel (II) chloride (source of the $\mathrm{Ni}$ ions), sodium borohydride (reducing agent), ethylenediamine (complexing compound), sodium hydroxide ( $\mathrm{pH}$ correction), lead nitrate (stabilizer), and graphene in the form of an aqueous 
suspension. From the manufacturer's description (Ref 27), the product consists of a single layer of graphene oxide with a concentration of $500 \mathrm{mg} / \mathrm{dm}^{3}$ with a carbon content of $79 \mathrm{wt} . \%$ and oxygen content of 20 wt.\%. The size of the graphene flakes were in the range $0.3-0.7 \mu \mathrm{m}$. The composition of the plating bath and process parameters are given in Table 1.

To properly disperse graphene in the bath during processing, the solution was mechanically stirred at $200 \mathrm{rpm}$. The applied mixing provides a uniform concentration of the solution components and even dispersal of the phase particles in the bath and counteracts pitting, which is formed as a result of hydrogen evolution (Ref 18). The deposition process was carried out for $2 \mathrm{~h}$ to obtain coatings $\sim 20 \mu \mathrm{m}$ thick. The deposition conditions for all coatings were the same. For each case, a minimum of two coatings was produced.

Graphene oxide was analyzed by Raman spectroscopy (inVia Reflex Renishaw System, 532 nm, green laser), scanning electron microscope (SEM) using a Jeol JSM-IT100 LA, and using transmission electron microscopy (TEM) Libra 120 ZEISS. The structure of Ni-B and composite Ni-B/GO coatings were examined by electron diffraction and $\mathrm{x}$-ray diffraction with a Rigaku ULTIMA IV diffractometer using the radiation of a $1.54 \AA$ copper tube. The topography and morphology of the $\mathrm{Ni}-\mathrm{B}$ and $\mathrm{Ni}-\mathrm{B} /$ graphene coatings were analyzed using SEM and light microscopes with the KEYENCE VHX 5000 digital microscope. The incorporation of graphene into the coating was studied by means of surface Raman spectroscopy

\section{Table 1 Composition of Ni-B plating bath}

\begin{tabular}{lll}
\hline Substance & Concentration & \multicolumn{1}{c}{ Producer } \\
\hline $\mathrm{NiCl}_{2} * 6 \mathrm{H}_{2} \mathrm{O}$ & $30 \mathrm{~g} / \mathrm{dm}^{3}$ & Chempur (Poland) \\
$\mathrm{NaBH}_{4}$ & $1.6 \mathrm{~g} / \mathrm{dm}^{3}$ & Sigma-Aldrich (USA) \\
$\mathrm{C}_{2} \mathrm{H}_{8} \mathrm{~N}_{2}$ & $90 \mathrm{~g} / \mathrm{dm}^{3}$ & Chempur (Poland) \\
$\mathrm{NaOH}$ & $90 \mathrm{~g} / \mathrm{dm}^{3}$ & Chempur (Poland) \\
$\mathrm{PbNO}$ & $0.0145 \mathrm{~g} / \mathrm{dm}^{3}$ & Chempur (Poland) \\
$\mathrm{GO}$ & $1 \mathrm{~cm}^{3} / \mathrm{dm}^{3}$ & GrapheneSupermarket (USA)
\end{tabular}

$T=363 \mathrm{~K}, \mathrm{pH} 14$, mechanical agitation: $200 \mathrm{rev} / \mathrm{min}$., $t=7200 \mathrm{~s}$ of the composite Ni-B/graphene coating. For microscopic and XRD examinations, sample fragments (about $1 \mathrm{~cm}^{2}$ ) were cut off and then washed in warm water and ethyl alcohol. The microstructure and EDS analysis of the produced coatings was tested on cross sections perpendicular to the surface using SEM. The cross-section samples for metallographic tests were incorporated into a conductive thermosetting resin. The composite was then mechanically ground using 200-1000 gradation papers. The final polishing stage was completed on a canvas using diamond paste. Knoop microhardness measurements were made using the Wilson Hardness T1202 tester (Buehler) at a load of $25 \mathrm{G}$ (HK0.025) on a cross section perpendicular to the surface on two samples, with 10 measurements for each sample. Corrosion tests were performed using an electrochemical potentiodynamic method in $0.5 \mathrm{M} \mathrm{NaCl}$ environment at $24{ }^{\circ} \mathrm{C} \pm 2{ }^{\circ} \mathrm{C}$ using a Bio-Logic potentiostat SP-200 with two samples for each variant. The measurements were carried out using a three-electrode arrangement: calomel electrode (reference electrode), platinum net (counter electrode), and the test sample (working electrode) with a working surface of $1 \mathrm{~cm}^{2}$. Polarization studies were conducted over a range from -250 to $250 \mathrm{mV}$ relative to the stationary potential. The scanning rate was taken as $0.2 \mathrm{mV} \mathrm{s}^{-1}$. The extrapolation tangent line to the polarization, $E=f(j)$ curve, from the cathode and anode areas was used to determine the corrosion current density $\left(j_{\text {corr }}\right)$ and corrosion potential $\left(E_{\text {corr }}\right)$.

\section{Results and Discussion}

\subsection{Graphene Oxide}

The SEM and TEM images of graphene oxide used to produce the $\mathrm{Ni}-\mathrm{B} /$ graphene composite coatings are shown in Fig. 1.

SEM and TEM images show that the used graphene flakes have various shapes and dimensions with a size range of 0.3 to $0.7 \mu \mathrm{m}$. The Raman spectrum of the graphene oxide is presented in Fig. 2.
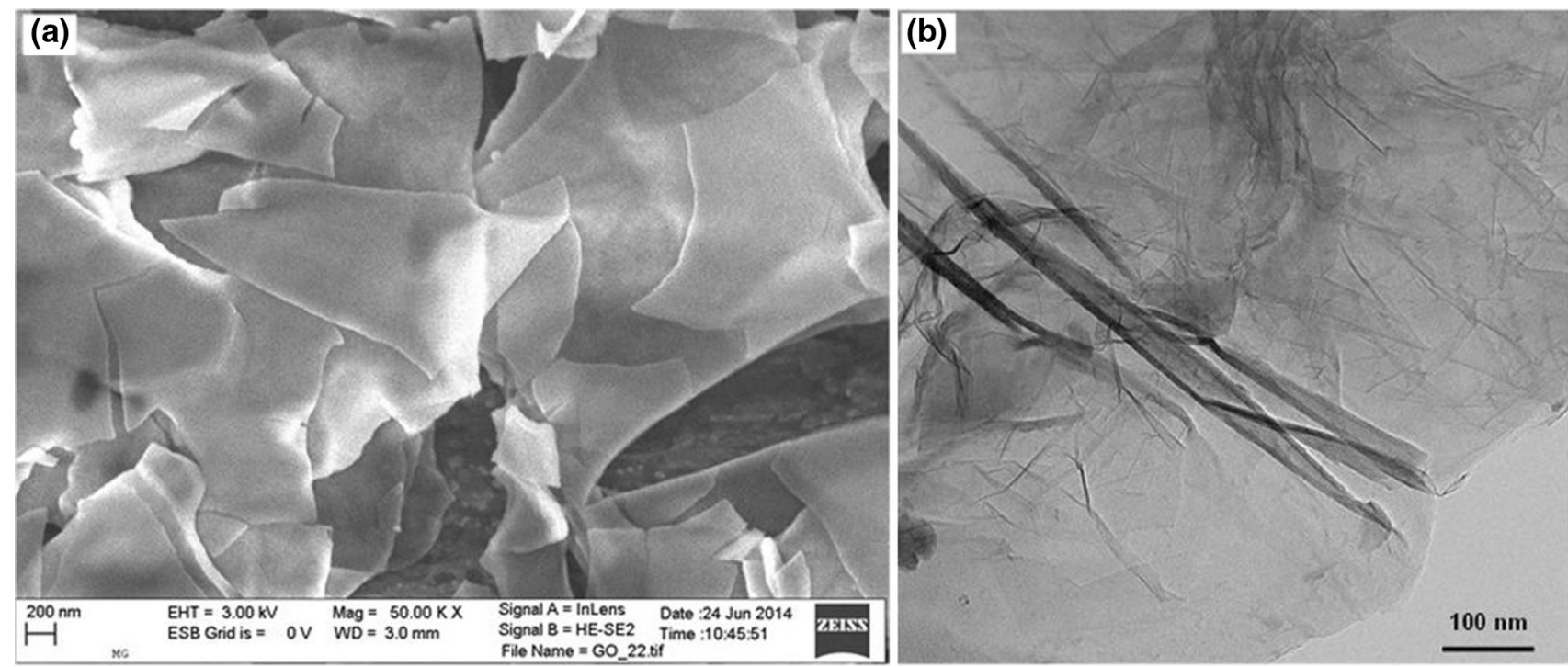

Fig. 1 Images of graphene oxide: SEM (a) and TEM (b) 


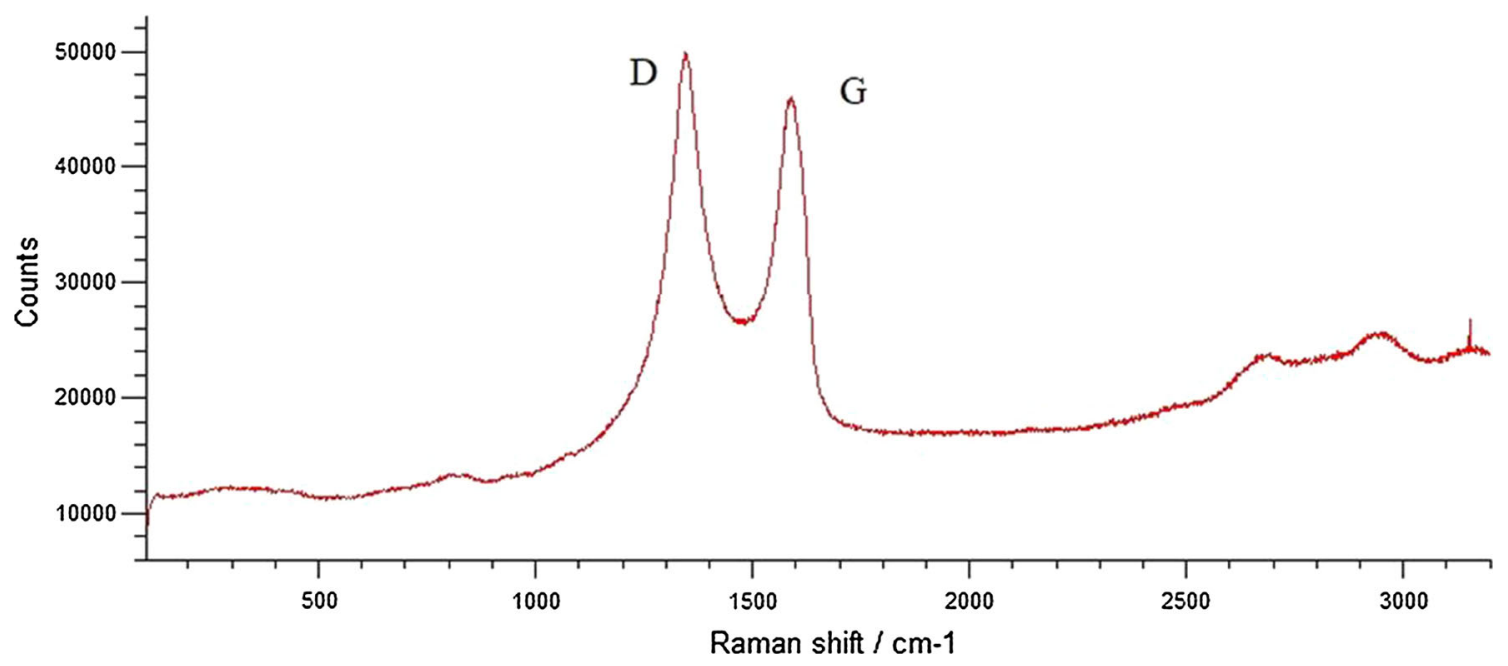

Fig. 2 Raman spectrum of graphene oxide

The Raman spectra show peaks which represent $D$ $\left(1350 \mathrm{~cm}^{-1}\right)$ and $G\left(1585 \mathrm{~cm}^{-1}\right)$ which are typical for graphene oxide. Peak $D$ is associated with defects in the material, and these are present at the edges of the flakes. Peak $G$ is typical for carbon materials with $s p^{2}$ hybridization between carbon atoms. The ratio of the intensity of the $I_{\mathrm{D}} / I_{\mathrm{G}}$ peaks determines the degree of disturbances in the structure of the material $(\operatorname{Ref} 28,29)$. In graphene oxide, the $I_{\mathrm{D}} / I_{\mathrm{G}}$ ratio is 1.18 which shows that this material has a very high disorder.

\subsection{Coatings Characterization}

3.2.1 Structure and Morphology of the Coatings. The structure of the Ni-B and composite Ni-B/graphene coatings was examined by $\mathrm{x}$-ray diffraction. The diffraction spectra of the produced coatings are given in Fig. 3.

$\mathrm{X}$-ray diffraction (XRD) results of the produced coatings revealed the presence of one wide peak centered at a $2 \theta$ of $45^{\circ}$, which corresponds to nickel (Ref 20) and according to Anik et al. (Ref 30) suggests an amorphous nature of the produced coatings. However, in Ref 14, the authors also show that a nanocrystalline structure of this type of material is possible. The results here show that the Ni-B alloy produced under the tested conditions is a mixture of amorphous and nanocrystalline phases. The content of the alloying components has a decisive influence on the type of structure of these materials. With an increase in the boron content in the coating, the proportion of the amorphous phase increases. At low boron contents, up to $5 \mathrm{wt} . \%$, the materials have a mixed amorphous-crystalline structure (Ref 18, 31). The EDS analysis of the coatings produced is shown in Table 2 .

Figure 4 shows the structure of the Ni-B matrix materials as analyzed by electron diffraction pattern.

The "fuzzy rings" in the electron diffraction pattern image reflect the short-range order of the amorphous materials. The surface images of the Ni-B and composite Ni-B/GO coatings are shown in Fig. 5.

The Ni-B and Ni-B/graphene coatings produced by the chemical reduction method have various morphologies. For the $\mathrm{Ni}-\mathrm{B}$ coatings, there are cauliflower-like structures present on the surface of these materials (Ref 13, 21, 30). The composite coating with embedded graphene oxide shows a much higher degree of surface development (Fig. 6) due to the incorporation
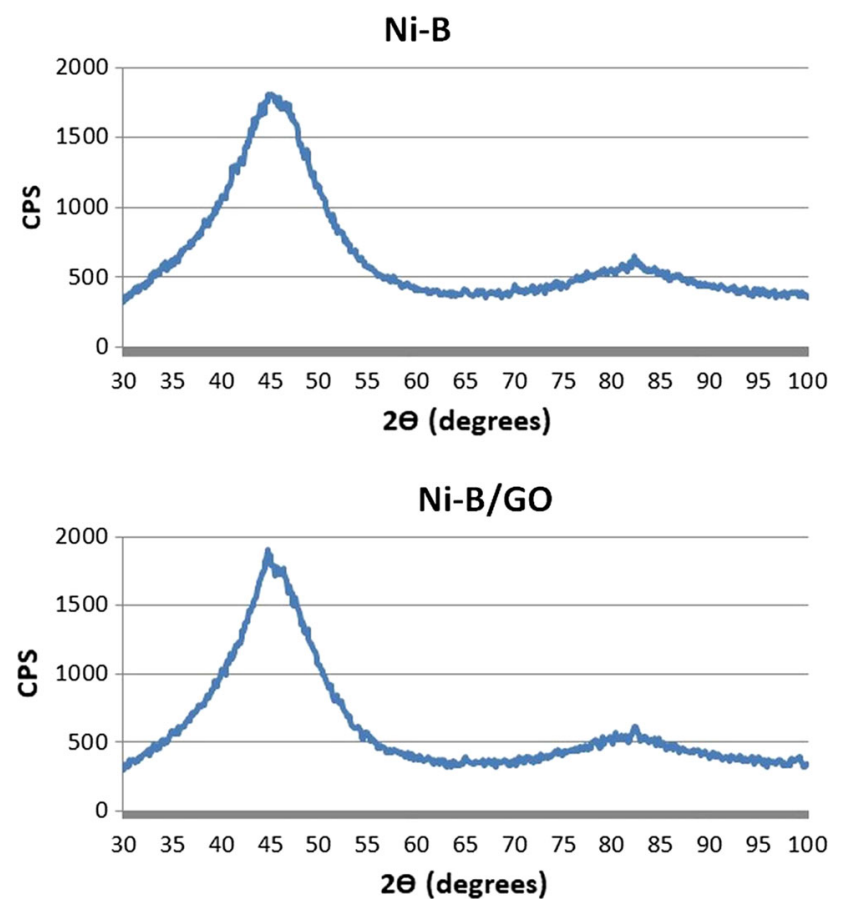

Fig. 3 X-ray diffraction pattern: Ni-B and Ni-B/GO

Table 2 Chemical composition of the Ni-B coating

\begin{tabular}{lcr}
\hline Element & Mass\% & Atom\% \\
\hline $\mathrm{B}$ & 3.00 & 13.74 \\
$\mathrm{C}$ & 1.05 & 4.34 \\
$\mathrm{O}$ & 0.47 & 1.44 \\
$\mathrm{Ni}$ & 95.48 & 80.47 \\
\hline
\end{tabular}

of graphene particles into the Ni-B matrix. When anchored to the coating, flakes of graphene oxide are embedded in the Ni-B matrix, which results in a large degree of surface development (Fig. 7). Similar effects are described in the works by, among others, Yu et al. (Ref 32) and Lee (Ref 33). Co-depositing of coating and dispersion phases can be influenced by many 
factors such as the composition of the solution, the type and shape of the particles in the dispersion phase, and the conditions of the deposition process (Ref 34). Matsubara

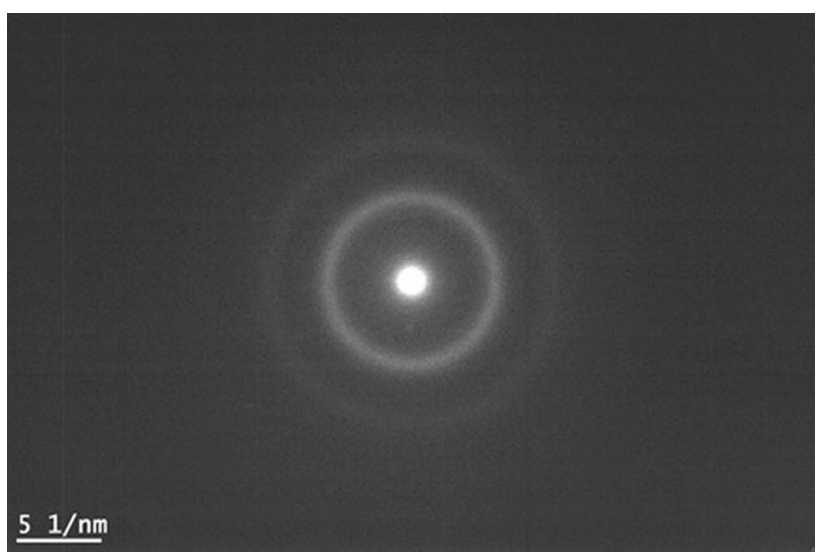

Fig. 4 Electron diffraction pattern of the Ni-B matrix material
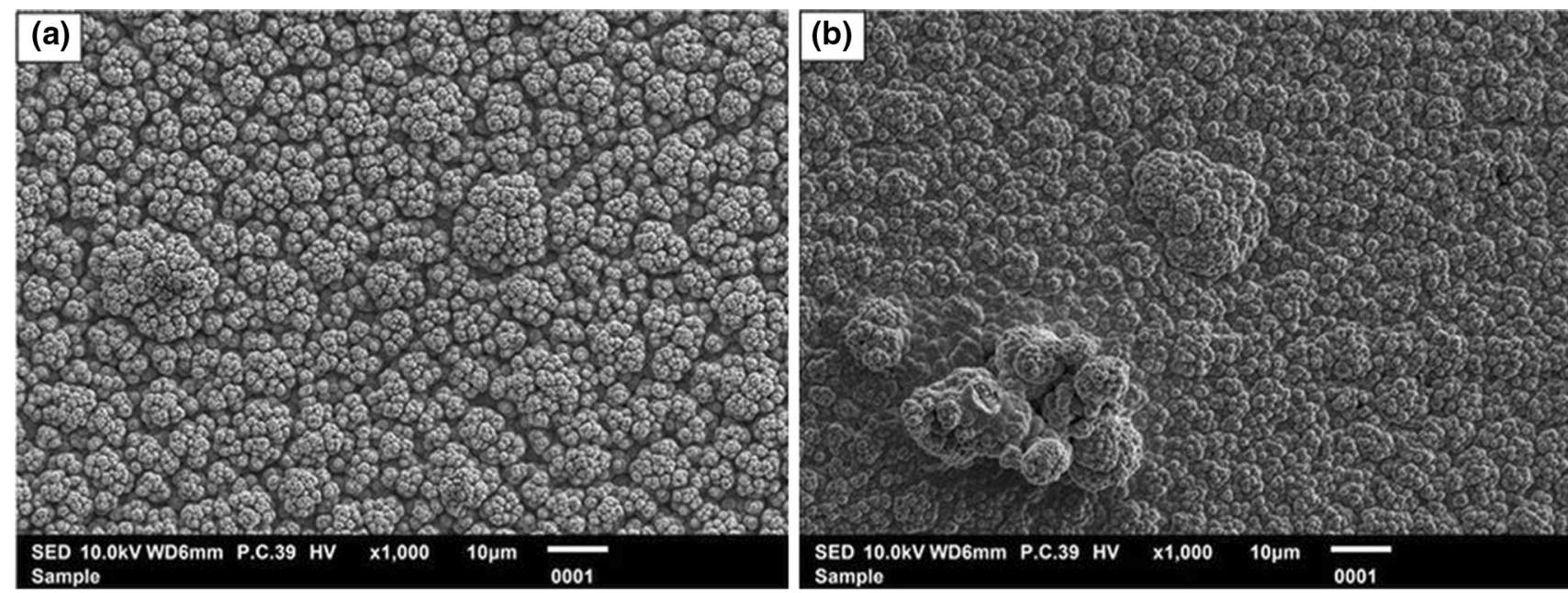

et al. (Ref 35) described the mechanism of co-deposition of nanodiamond particles in Ni-P coatings deposited by an electroless method. The theory developed suggests that nickel ions are absorbed on the surface of the particles of the dispersion phase and then reduced to a metallic form in the coating. For particles with a large specific surface, such as diamond or graphene, nickel ions can be more readily absorbed on them, which in turn leads to a larger number of embedded particles.

The microstructure of the produced $\mathrm{Ni}-\mathrm{B}$ and composite $\mathrm{Ni}$ $\mathrm{B} /$ graphene coatings in cross sections perpendicular to their surfaces is shown in Fig. 7.

The coatings produced by electroless deposition are characterized by a compact structure and thickness $\sim 20 \mu \mathrm{m}$. SEM images taken from the cross section show good adhesion of the coating to the steel substrate. The cross section of the Ni-B and composite Ni-B/graphene coatings exhibits a column structure typical for this type of material. The formation of such structures can be explained by the diffusion of the reactive bath components during the deposition process (Ref 13). Images of the cross sections for the produced coatings confirm earlier results showing a greater degree of surface development, with

Fig. 5 Surface images of the coatings (SEM): (a) Ni-B and (b) Ni-B/GO
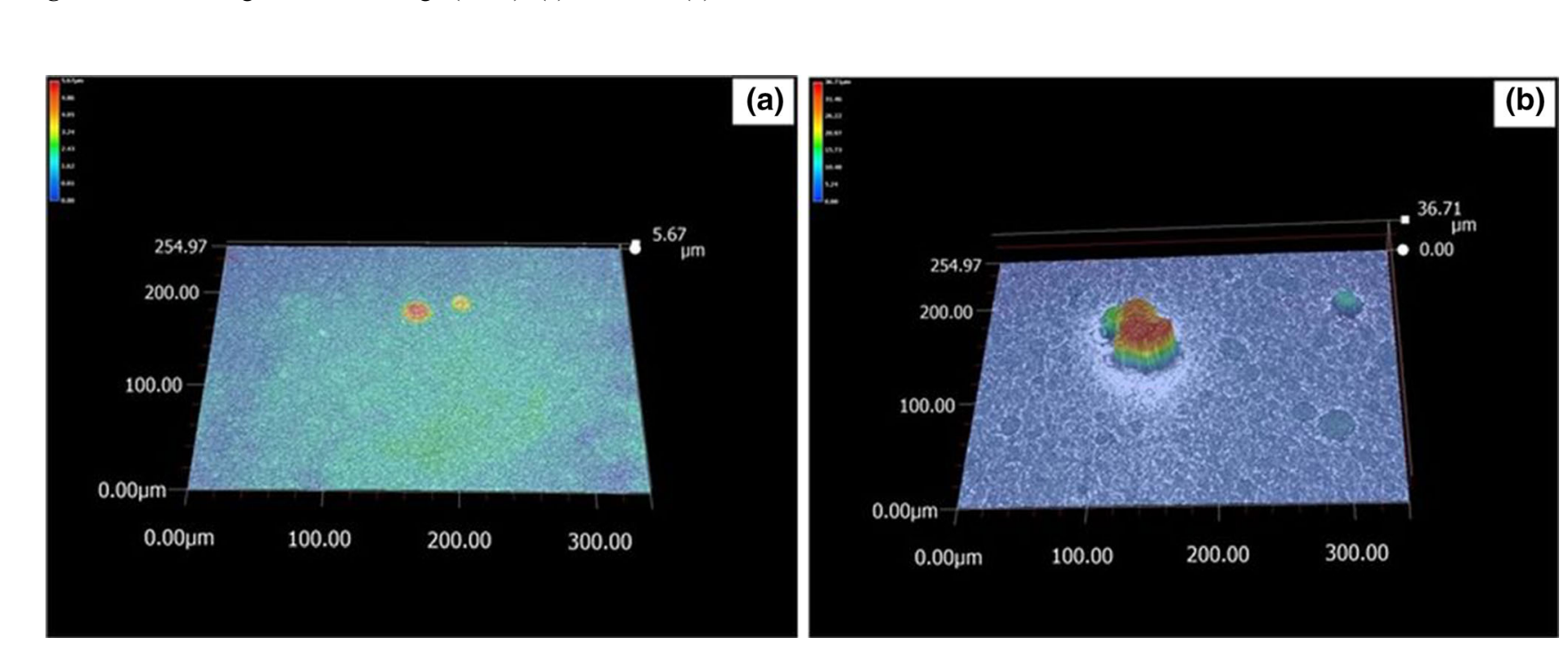

Fig. 6 Topography of the coatings surface (light microscope): (a) Ni-B and (b) Ni-B/GO 

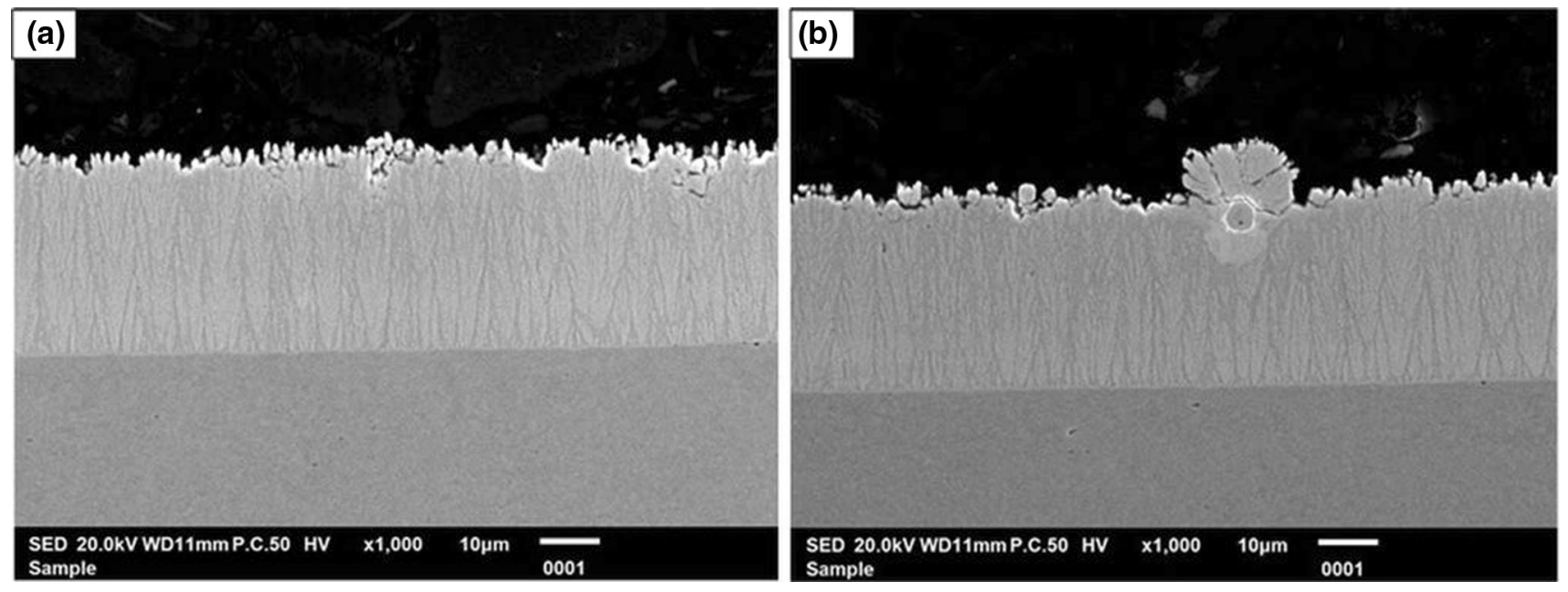

Fig. 7 Cross sections of coatings (SEM): (a) Ni-B and (b) Ni-B/GO

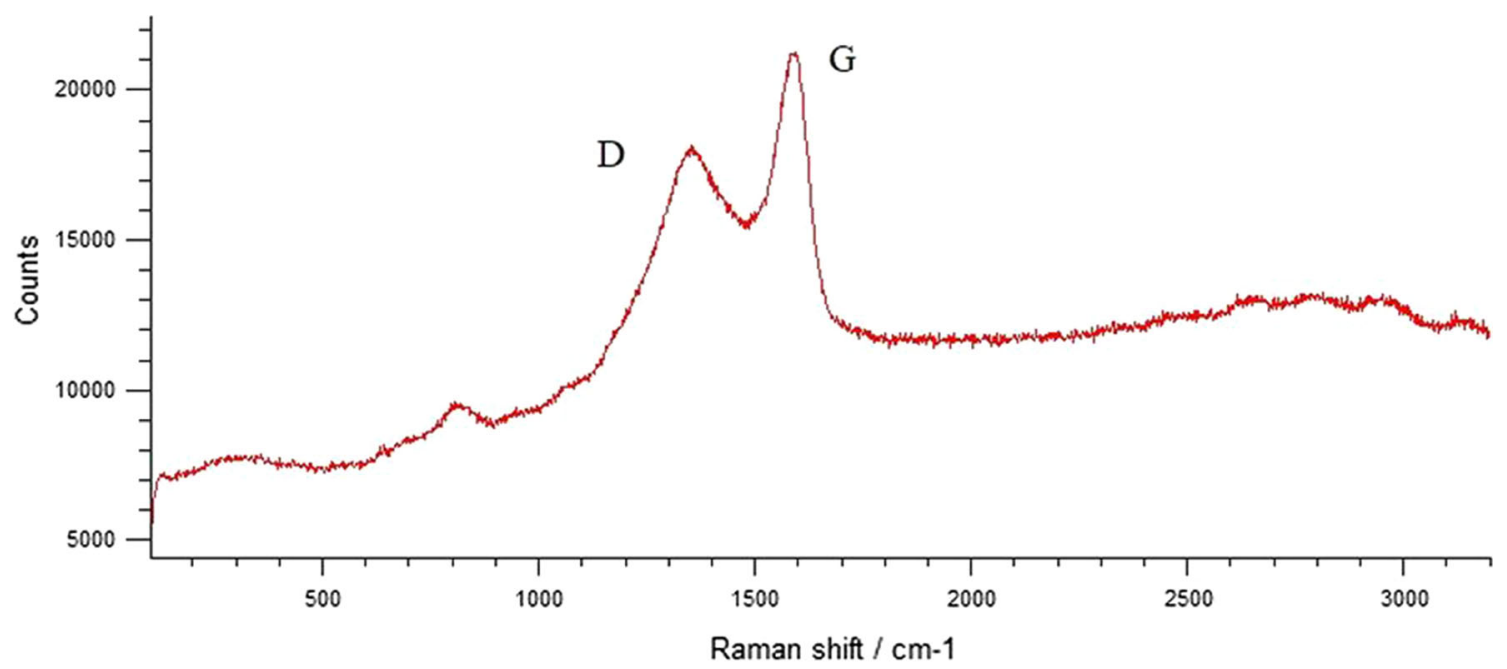

Fig. 8 Raman spectrum of the Ni-B/GO composite coating

characteristic convex areas on the surface of the coatings, demonstrating the incorporation of the graphene dispersive phase. The confirmation of the incorporation of graphene oxide into the Ni-B matrix is also provided by the Raman spectrum of the Ni-B/graphene composite coating shown in Fig. 8.

The Raman spectrum of the Ni-B/graphene composite coating shows two peaks which are characteristic for graphene oxide - the peak $D$ at approximately $1350 \mathrm{~cm}^{-1}$ and peak $G$ $\left(1580 \mathrm{~cm}^{-1}\right)$, and the results of these studies confirm the incorporation of graphene oxide into the Ni-B coating material. The intensity ratio between $I_{\mathrm{D}} / I_{\mathrm{G}}$ is equal to 0.79 and indicates an increase in the ordering of the tested material after incorporation into the Ni-B matrix. This can be explained by the arrangement of graphene flakes in the coating, as their arrangement is less disordered when compared to the study of the flakes themselves.

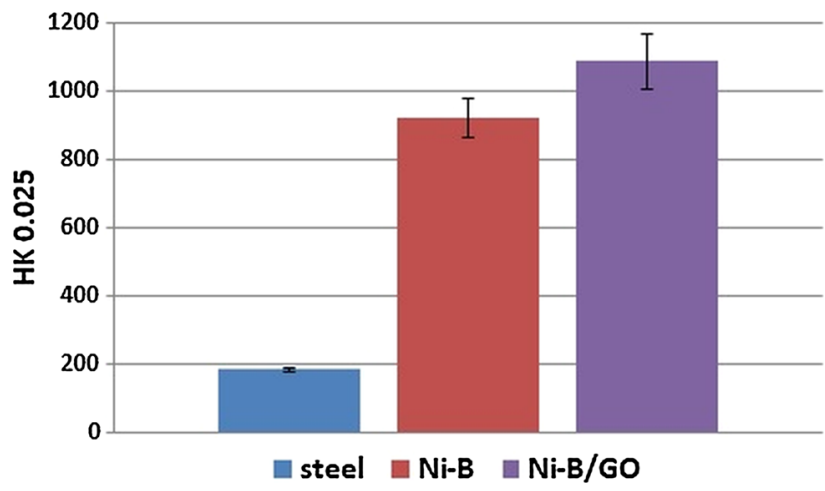

Fig. 9 Microhardness of the produced coatings and substrate material (steel) 
Table 3 Microhardness and statistical evaluation of the produced coatings and substrate material (steel)

\begin{tabular}{|c|c|c|c|c|c|c|}
\hline \multirow[b]{2}{*}{ No. } & \multicolumn{2}{|c|}{ Steel } & \multicolumn{2}{|c|}{ Ni-B } & \multicolumn{2}{|c|}{ Ni-B/GO } \\
\hline & Sample 1 & Sample 2 & Sample 1 & Sample 2 & Sample 1 & Sample 2 \\
\hline 1 & 171 & 181 & 939 & 849 & 1170 & 1010 \\
\hline 2 & 181 & 193 & 972 & 972 & 1040 & 1010 \\
\hline 3 & 190 & 184 & 972 & 972 & 1040 & 1040 \\
\hline 4 & 184 & 181 & 972 & 849 & 1080 & 1010 \\
\hline 5 & 181 & 181 & 849 & 878 & 1010 & 1260 \\
\hline 6 & 184 & 190 & 972 & 878 & 1080 & 1080 \\
\hline 7 & 187 & 171 & 878 & 972 & 1120 & 1170 \\
\hline 8 & 193 & 181 & 849 & 878 & 1260 & 1010 \\
\hline 9 & 181 & 184 & 849 & 972 & 1170 & 1080 \\
\hline 10 & 199 & 171 & 972 & 972 & 1010 & 1080 \\
\hline Average & 183 & & 921 & & 1087 & \\
\hline Standard deviation & 7.4 & & 56.0 & & 80.8 & \\
\hline Median & 182.5 & & 955.5 & & 1060 & \\
\hline Range & 28 & & 123 & & 250 & \\
\hline
\end{tabular}

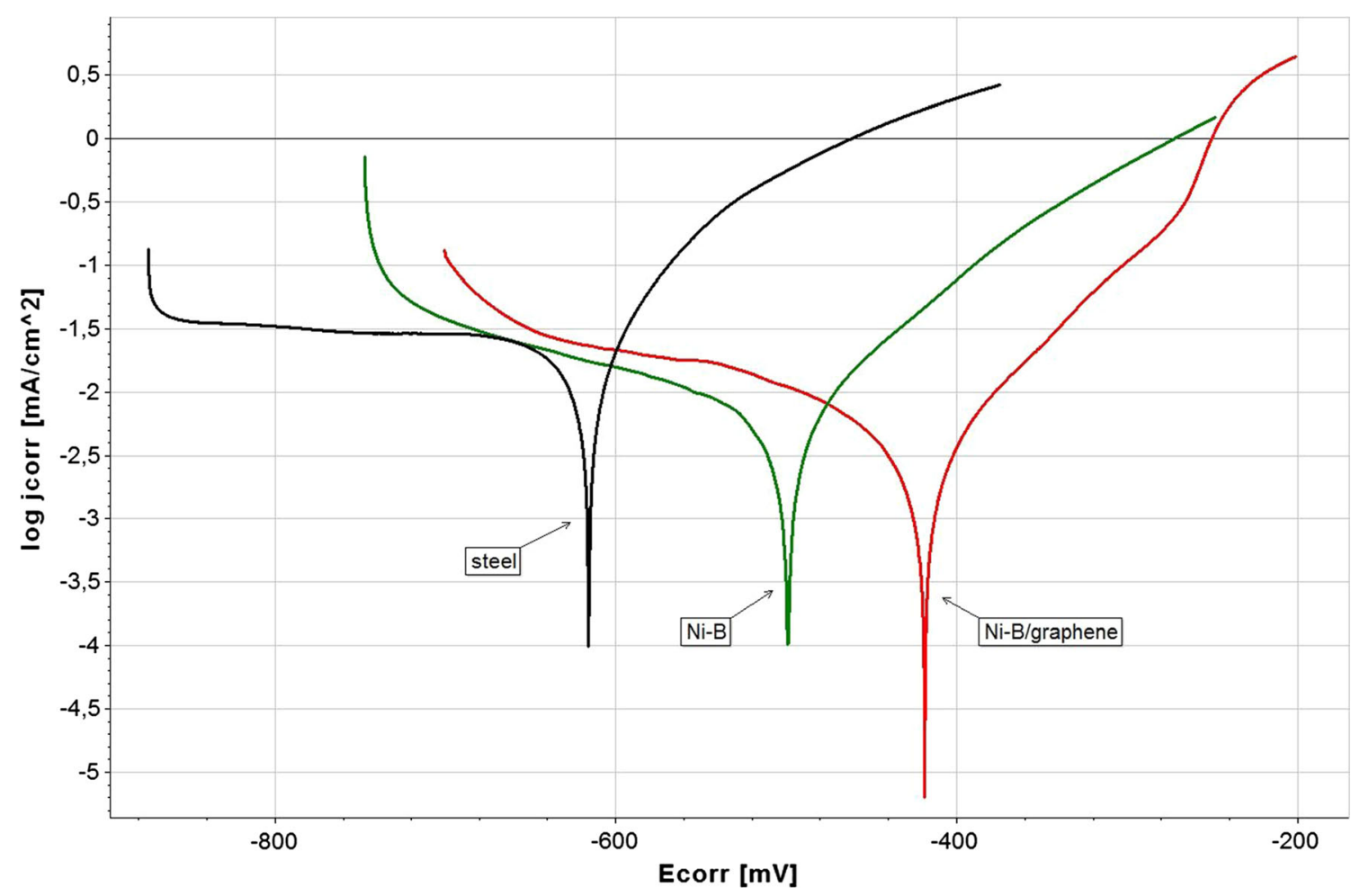

Fig. 10 Potentiodynamic polarization curves of tested materials

3.2.2 Microhardness. The performed studies attest that the incorporation of graphene oxide into the Ni-B coating directly affects its properties. The results of microhardness measurements of the Ni-B alloys, as well as composite NiB/graphene and steel substrates, are shown in Fig. 9 and Table 3.

All the produced coatings have a much higher hardness than a steel substrate. The Ni-B alloy coatings deposited by the electroless method are characterized by a very high hardness, which is also confirmed by results published in Ref 19, 36. The incorporation of graphene into the Ni-B coating significantly increases the hardness of the coating material. The hardness of the produced $\mathrm{Ni}-\mathrm{B} /$ graphene composite coating is equal to
Table 4 Corrosion parameters of tested materials

\begin{tabular}{lcc}
\hline Sample & $\boldsymbol{E}_{\text {corr }} \mathbf{m V}$ & $\boldsymbol{j}_{\text {corr }} \boldsymbol{\mu} \mathbf{A} / \mathbf{c m}^{2}$ \\
\hline Steel & -616 & 16.0 \\
Ni-B & -499 & 6.9 \\
Ni-B/GO & -419 & 2.9 \\
\hline
\end{tabular}

$\sim 1100 \mathrm{HK} 0.025$. The high hardness of composite coatings can be explained by dispersion strengthening. Graphene particles after embedding contribute to blocking plastic deformations in the Ni-B matrix material (Ref 20). The hardness of Ni- 
$\mathrm{B} /$ graphene coatings is greater than that of $\mathrm{Ni}-\mathrm{P} /$ graphene coatings (Ref 23) and is similar to chromium coatings (Ref 25).

3.2.3 Corrosion Resistance. The produced Ni-B and composite $\mathrm{Ni}-\mathrm{B} /$ graphene coatings, as well as the steel substrate material, were subjected to corrosion tests. The results of corrosion tests given as potentiodynamic curves and the resultant corrosive parameters: corrosion potential $\left(E_{\text {corr }}\right)$ and corrosion current density $\left(j_{\text {corr }}\right)$ of the produced materials, are shown in Fig. 10 and Table 4.

The corrosion tests were carried out in a $0.5 \mathrm{M} \mathrm{NaCl}$ environment and showed that all the $\mathrm{Ni}-\mathrm{B}$ and composite $\mathrm{Ni}$ $\mathrm{B} /$ graphene coatings had significantly higher corrosion resistance than the steel substrate material. The Ni-B/graphene composite coating shows a greater corrosion resistance when compared to the Ni-B coating without embedded graphene oxide, as evidenced by a shift in the corrosion potential toward a less negative value and by reducing the corrosion current density of the composite coating with embedded graphene oxide. The corrosion process is controlled by the cathodic oxygen depolarization reaction and can be considered as the general corrosion mechanism in the studied process. This type of coating offers anodic protection and will only be effective if the coating is fully sealed. Research on similar materials has been reported by Tamilarasan et al. (Ref 23), who produced Ni$\mathrm{P}$ coatings with incorporated of the reduced graphene oxide. The results of these tests confirmed that the incorporation of graphene oxide affects the corrosion resistance of the nickel alloys deposited by a chemical reduction process. The mentioned authors explained the barrier effect of graphene oxide as the main improvement in the corrosion resistance.

\section{Conclusions}

In the performed research, $\mathrm{Ni}-\mathrm{B} /$ graphene composite coatings were produced using a chemical reduction method. The manufactured coatings of $\mathrm{Ni}-\mathrm{B}$ and $\mathrm{Ni}-\mathrm{B} /$ graphene composite are characterized by their amorphous and compact structure. Studies using microscopic methods and Raman spectroscopy confirm the incorporation of graphene oxide into the nickel (NiB) material of the matrix. The obtained results show that the incorporation of graphene oxide into the Ni-B coating improves the material's properties such as its hardness. The hardness of $\mathrm{Ni}-\mathrm{B} /$ graphene coatings is similar to that of chrome coatings. Moreover, corrosion tests in a $0.5 \mathrm{M} \mathrm{NaCl}$ environment show that graphene can improve corrosion resistance.

\section{Open Access}

This article is licensed under a Creative Commons Attribution 4.0 International License, which permits use, sharing, adaptation, distribution and reproduction in any medium or format, as long as you give appropriate credit to the original author(s) and the source, provide a link to the Creative Commons licence, and indicate if changes were made. The images or other third party material in this article are included in the article's Creative Commons licence, unless indicated otherwise in a credit line to the material. If material is not included in the article's Creative Commons licence and your intended use is not permitted by statutory regulation or exceeds the permitted use, you will need to obtain permission directly from the copyright holder. To view a copy of this licence, visit http://creativecommons.org/licenses/by/4.0/.

\section{References}

1. M. Czagány, P. Baumli, and G. Kaptay, The Influence of the Phosphorous Content and Heat Treatment on the Nano-Micro-Structure, Thickness and Micro-hardness of Electroless Ni-P Coatings on Steel, Appl. Surf. Sci., 2017, 423, p 160-169

2. Z.K. Karaguiozova, Characterisation of Electroless Ni-P and Electroless Composite Coatings Ni-P/Ni-PTFE, Int. J. Surf. Sci. Eng., 2018, 12(5/6), p 496-506

3. Y. Cai, S. Li, Z. Cheng, G. Xu, X. Quan, and Y. Zhou, Facile Fabrication of Super-Hydrophobic FAS Modified Electroless Ni-P Coating Meshes for Rapid Water-Oil Separation, Colloids Surf. A, 2018, 540, p 224-232

4. A. Ahmadi Ashtiani, S. Faraji, S. Amjad Iranagh, and A. Hossein Faraji, The Study of Electroless Ni-P Alloys with Different Complexing Agents on Ck45 Steel Substrate, Arab. J. Chem., 2017, 10, p 15411545

5. A. Stankiewicz, I. Szczygieł, and B. Szczygieł, Summary of Existing Models of the Ni-P Coating Electroless Deposition Process, Int. J. Chem. Kinet., 2013, 45, p 755-762

6. J. Bieliński, A. Broda, R. Kozera, A. Bielińska, A. Boczkowska, and K.J. Kurzydłowski, The Significance of Process Parameters in Electroles Ni-P Coating for Fabrication of Ni-P/C-Fibers Precomposite, Compos. Theory Pract., 2010, 10, p 206-212

7. J. Woźniak, M. Trzaska, G. Cieślak, T. Cygan, M. Kostecki, and A. Olszyna, Preparation and Mechanical Properties of Alumina Composites Reinforced with Nickel-Coated Graphene, Ceram. Int., 2016, 42, p 8597-8603

8. J.-R. Choi, Y.S. Lee, and S.-J. Park, A Study on Thermal Conductivity of Electroless Ni-B Plated Multi-walled Carbon Nanotubes-Reinforced Composites, J. Ind. Eng. Chem., 2014, 20, p 3421-3424

9. C.A. García-Aguirre, C. Domínguez-Ríos, R. Torres-Sánchez, M. Román-Aguirre, J.T. Holguín-Momaca, and A. Aguilar-Elguézabal, Microstructure and Transmission Electronmicroscopy Characterization of Electroless Ni-B Thin Films Deposited on MWCNTs, Surf. Coat. Technol., 2015, 282, p 107-114

10. A. Ikeda, A. Sakamoto, R. Hattori, and Y. Kuroki, Electroless Ni-B Plating on $\mathrm{SiO}_{2}$ with 3-Aminopropyl-triethoxysilane as a Barrier Layer Against $\mathrm{Cu}$ Diffusion for Through-Si via Interconnections in a 3Dimensional Multi-chip Package, Thin Solid Films, 2009, 517, p 17401745

11. M. Romero-Romero, C. Domínguez-Ríos, R. Torres-Sánchez, and A. Aguilar-Elguezabal, Electroless Ni-B Coating onto $\mathrm{TiH}_{2}$ Powder: An Approach for a Simplified Surface Preparation, Surf. Coat. Technol., 2017, 315, p 181-187

12. N. Beigi Khosroshahi, R. Azari Khosroshahi, R. Taherzadeh Mousavian, and D. Brabazon, Effect of Electroless Coating Parameters and Ceramic Particle Size on Fabrication of a Uniform Ni-P Coating on SiC Particles, Ceram. Int., 2014, 40, p 12149-12159

13. L. Bonin, N. Bains, V. Vitry, and A.J. Cobley, Electroless Deposition of Nickel-Boron Coatings Using Low Frequency Ultrasonic Agitation: Effect of Ultrasonic Frequency on the Coatings, Ultrasonics, 2017, 77, p 61-68

14. E. Correa, A.A. Zuleta, L. Guerra, M.A. Gómez, J.G. Castaño, F. Echeverría, H. Liu, P. Skeldon, and G.E. Thompson, Tribological Behavior of Electroless Ni-B Coatings on Magnesium and AZ91D Alloy, Wear, 2013, 305, p 115-123

15. Z. Abdel Hamid, H.B. Hassan, and A.M. Attyia, Influence of Deposition Temperature and Heat Treatment on the Performance of Electroless Ni-B Films, Surf. Coat. Technol., 2010, 205, p 2348-2354

16. A. Mukhopadhyay, T.K. Barman, and P. Sahoo, Tribological Behavior of Sodium Borohydride Reduced Electroless Nickel Alloy Coatings at Room and Elevated Temperatures, Surf. Coat. Technol., 2017, 321, p 464-476

17. M. Vijayanand and R. Elansezhian, Effect of Different Pretreatments and Heat Treatment on Wear Properties of Electroless Ni-B Coatings on 7075-T6 Aluminum Alloy, Procedia Eng., 2014, 97, p 1707-1717

18. E. Georgiza, V. Gouda, and P. Vassiliou, Production and Properties of Composite Electroless Ni-B-SiC Coatings, Surf. Coat. Technol., 2017, 325, p 46-51 
19. B. Lia, W. Zhangb, Y. Huana, and J. Dong, Synthesis and Characterization of $\mathrm{Ni}-\mathrm{B} / \mathrm{Al}_{2} \mathrm{O}_{3}$ Nanocomposite Coating by Electrodeposition Using Trimethylamine Borane as Boron Precursor, Surf. Coat. Technol., 2018, 337, p 186-197

20. V. Niksefat and M. Ghorbani, Mechanical and Electrochemical Properties of Ultrasonic-Assisted Electroless Deposition of Ni-B$\mathrm{TiO}_{2}$ Composite Coatings, J. Alloys Compd., 2015, 633, p 127-136

21. A. Mazurek, G. Cieślak, W. Bartoszek, and M. Trzaska, Właściwości korozyjne warstw kompozytowych Ni-B/ $\mathrm{Si}_{3} \mathrm{~N}_{4}$ wytwarzanych bezprądowo, Inżynieria Powierzchni, 2017, 4, p 28-32

22. M. Trzaska and G. Cieślak, Composites Layers of Ni-P/Graphene Produced by Chemical Reduction Method, Compos. Theory Pract., 2015, 3, p 137-140

23. T.R. Tamilarasan, U. Sanjith, M. Siva Shankar, and G. Rajagopal, Effect of Reduced Graphene Oxide (rGO) on Corrosion and ErosionCorrosion Behaviour of Electroless Ni-P Coatings, Wear, 2017, 390391, p 385-391

24. H. Wu, F. Liu, W. Gong, F. Ye, L. Hao, J. Jiang, and S. Han, Preparation of Ni-P-GO Composite Coatings and Its Mechanical Properties, Surf. Coat. Technol., 2015, 272, p 25-32

25. Z. Zeng et al., The Correlation Between the Hardness and Tribological Behaviour of Electroplated Chromium Coatings Sliding Against Ceramic and Steel Counterparts, Surf. Coat. Technol., 2006, 201, p 2282-2288

26. J. Skowron and K. Konieczko, Occupational Exposure to Chromium(VI) Compounds, Med. Pr., 2015, 66(3), p 407-427

27. https://graphene-supermarket.com/Dispersion-in-Water-Single-LayerGraphene-Oxide-175-ml.html. Accessed 25 Apr 2018

28. W. Konicki, M. Aleksandrzak, and E. Mijowska, Equilibrium and Kinetics Studies for the Adsorption of $\mathrm{Ni}^{2+}$ and $\mathrm{Fe}^{3+}$ Ions from Aqueous Solution by Graphene Oxide, Pol. J. Chem. Technol., 2017, 19(3), p 120-129
29. M. Mirzaee, C. Dehghanian, and K. Sabet Bokati, One-Step Electrodeposition of Reduced Graphene Oxide on Three-Dimensional Porous Nano Nickel-Copper Foam Electrode and Its Use in Supercapacitor, J. Electroanal. Chem., 2018, 813, p 152-162

30. M. Anik, E. Körpe, and E. Sen, Effect of Coating Bath Composition on the Properties of Electroless Nickel-Boron Films, Surf. Coat. Technol., 2008, 202, p 1718-1727

31. I. Baskaran, R. Sakthi Kumar, T.S.N. Sankara Narayanan, and A. Stephen, Surf. Coat. Technol., 2006, 200, p 6888-6894

32. Q. Yu, T. Zhoua, Y. Jiang, X. Yanb, Z. Anc, X. Wanga, D. Zhang, and T. Ono, Preparation of Graphene-Enhanced Nickel-Phosphorus Composite Films by Ultrasonic-Assisted Electroless Plating, Appl. Surf. Sci., 2018, 435, p 617-625

33. C.-K. Lee, Electroless NiCuP/Nano-graphite Composite Coatings for Bipolar Plates of Proton Exchange Membrane Fuel Cells, J. Power Sources, 2012, 220, p 130-137

34. A. Hovestad and L.J.J. Janssen, Electrochemical Codeposition of Inert Particles in a Metallic Matrix, J. Appl. Electrochem., 1995, 25, p 519527

35. H. Matsubara et al., Co-deposition Mechanism of Nanodiamond with Electrolessly Plated Nickel Films, Electrochim. Acta, 2007, 52, p 3047-3052

36. V. Vitry and L. Bonin, Increase of Boron Content in Electroless NickelBoron Coating by Modification of Plating Conditions, Surf. Coat. Technol., 2017, 311, p 164-171

Publisher's Note Springer Nature remains neutral with regard to jurisdictional claims in published maps and institutional affiliations. 